\title{
A Curious Case of Cutaneous Horn
}

\author{
Gorrepati Rohith ${ }^{1}$, Souradeep Dutta ${ }^{2}$, Sreenath G. S. ${ }^{2}$ \\ 1. General Surgery, Jawaharlal Institute of Postgraduate Medical Education and Research, Puducherry, IND 2. Surgery, \\ Jawaharlal Institute of Postgraduate Medical Education and Research, Puducherry, IND
}

Corresponding author: Sreenath G. S., dr.sreenathgs@gmail.com

\begin{abstract}
Cutaneous horns are uncommon lesions that occur as conical projections in various sun-exposed parts of the body. They are made of hyperkeratotic material and look similar to animal horns. These lesions lack a central bony core that differentiates them from the animal horns. They are frequently associated with various benign, premalignant, and malignant lesions, and therefore carry a clinical significance. We present a case of a 58-year-old gentleman who presented with a conical projection over the center of the forehead, which was clinically diagnosed as a cutaneous horn. Excision of the horn along with the base was done, and the histopathology revealed benign seborrheic keratosis as the underlying lesion. The excision of small lesions along with their bases or biopsy of the base of large lesions is of paramount importance in the management of cutaneous horns.
\end{abstract}

Categories: Dermatology, Plastic Surgery, General Surgery

Keywords: cutaneous horn

\section{Introduction}

Cutaneous horns (cornu cutaneum/devil's horn) are unusual epidermal hyperkeratotic lesions resembling an animal horn [1]. Most of these lesions occur in varied shapes either curved or straight. Their size may range from few millimeters to several centimeters. They mostly occur in sun-exposed parts, such as the face, forearms, and dorsum of hands [2]. There appears to be no sex predilection, but the chances of presence of malignancy at the lesion's base are more in males compared to females [3]. Around 60\% of these lesions are benign, whereas the rest of the lesions may harbor a variety of premalignant or malignant conditions at their base [4]. Owing to this, shaving the lesion off its base is discouraged and complete excision of the lesion along with the base followed by complete histopathological examination is to be carried out to identify the underlying pathology [5].

\section{Case Presentation}

A 58-year-old gentleman, who is an agricultural laborer by occupation, presented to the outpatient department with a conical lesion over the center of his forehead (Figure 1) for the past three years.

Received 08/31/2020

Review began 09/03/2020 Review ended 09/04/2020 Published 09/05/2020

(c) Copyright 2020

Rohith et al. This is an open access article distributed under the terms of the Creative Commons Attribution License CC-BY 4.0., which permits unrestricted use, distribution, and reproduction in any medium, provided the original author and source are credited.

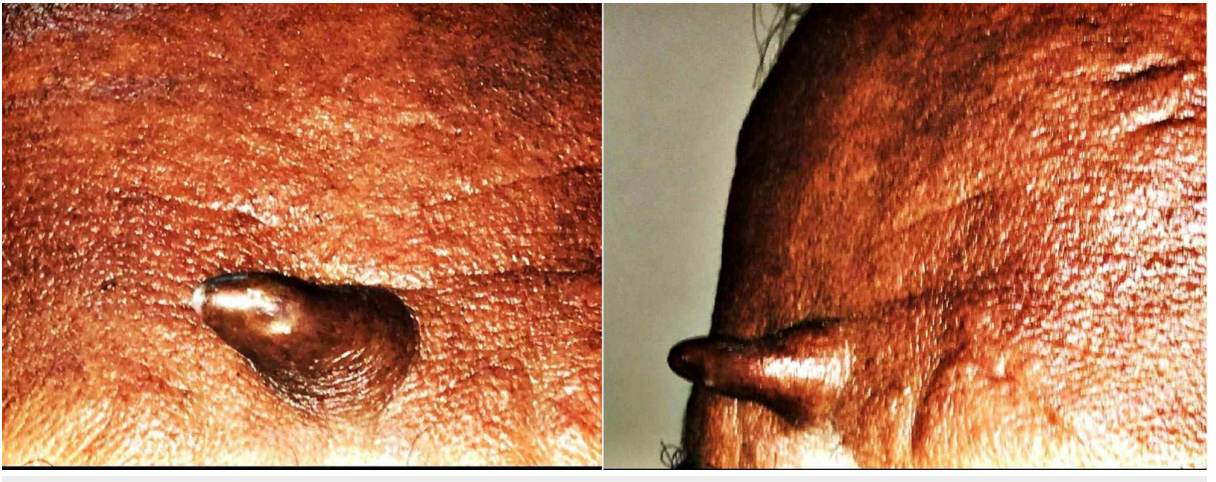

FIGURE 1: A 1.5-cm long cutaneous horn on the center of forehead.

The lesion was slowly increasing in size to attain the present size. The lesion was painless. He had no history of trauma and did not give any history of similar complaints. He was a chronic smoker for the past 15 years. He is a known case of well-controlled hypertension on regular medication. Owing to his daily outdoor working conditions, he had a prolonged history of sun exposure.

On examination, the lesion was $1.5 \mathrm{~cm}$ in length. It was non-tender and firm to hard in consistency. He had no other similar swellings over his body. Excision of the lesion along with the base was performed following 
which the histopathology examination showed features of benign seborrheic keratosis. There were no features of malignancy.

\section{Discussion}

In the year 1588, cornu cutaneum was first documented in an elderly Welsh lady, Mrs. Margaret Gryffith [3]. They are relatively rare in Asian and African populations compared to Caucasians. This can be attributed to the protective action of melanin against ultraviolet radiation, which is believed to play a role in its etiology [4]. These cutaneous horns, although grossly similar, differ significantly from animal horns by the absence of an axial well-formed bone around which the hyperkeratotic epidermis and dermis are placed [6].

These lesions were previously associated with historic perplexity, and patients with these cutaneous horns were exhibited by money. Yu et al. had reported a totality of 643 patients with cutaneous horns over a period of 10 years with an annual frequency of 32 cases [7]. At around the same time, 48 patients were reported by Mencia-Gutierrez et al. [8].

The diagnosis is mostly clinical, and they are usually seen in association with several benign and malignant lesions at their bases. The horn being just an epidermal outgrowth of dead keratin is of little significance, but a striking aspect of this lesion is the underlying condition at its base which may be benign (seborrheic keratosis, keratotic acanthoma, viral wart, trichelemmoma, etc), premalignant (Bowen's disease, solar keratosis), or malignant (verrucous carcinoma [9], squamous cell carcinoma [10], basal cell carcinoma [11], epidermoid carcinoma, malignant melanoma) [3].

\section{Conclusions}

Cutaneous horns are relatively common in Caucasian populations compared to African-Asian populations. Although most of these lesions are benign, there is a potential chance of these lesions harboring a malignant condition at their base that occurs in almost one-third of the cases.

Thus, excision of the lesion with its base along with histopathological examination forms the mainstay of the treatment.

\section{Additional Information \\ Disclosures}

Human subjects: Consent was obtained by all participants in this study. Conflicts of interest: In compliance with the ICMJE uniform disclosure form, all authors declare the following: Payment/services info: All authors have declared that no financial support was received from any organization for the submitted work. Financial relationships: All authors have declared that they have no financial relationships at present or within the previous three years with any organizations that might have an interest in the submitted work. Other relationships: All authors have declared that there are no other relationships or activities that could appear to have influenced the submitted work.

\section{References}

1. Montgomery DW: Cornu cutaneum. Arch Derm Syphilol. 1941, 44:231-235. 10.1001/archderm.1941.01500020086008

2. Ramdass MJ: The curled sebaceous horn. Clin Case Rep. 2015, 4:118-119. 10.1002/ccr3.454

3. Copcu E, Sivrioglu N, Culhaci N: Cutaneous horns: are these lesions as innocent as they seem to be? . World J Surg Oncol. 2004, 2:18. 10.1186/1477-7819-2-18

4. Phulari RG, Rathore R, Talegaon TP, Shah A: Cutaneous horn: a mask to underlying malignancy . J Oral Maxillofac Pathol. 2018, 22:87-90. 10.4103/jomfp.JOMFP_156_17

5. Haddad CJ, Haddad-Lacle JEM: Cutaneous horn: get to the bottom of it. BMJ Case Rep. 2014, 2014:bcr2014204447. 10.1136/bcr-2014-204447

6. Michal M, Bisceglia M, Di Mattia A, et al.: Gigantic cutaneous horns of the scalp: lesions with a gross similarity to the horns of animals: a report of four cases. Am J Surg Pathol. 2002, 26:789-794. 10.1097/00000478-200206000-00014

7. Yu RC, Pryce DW, Macfarlane AW, Stewart TW: A histopathological study of 643 cutaneous horns . Br J Dermatol. 1991, 124:449-452. 10.1111/j.1365-2133.1991.tb00624.x

8. Mencia-Gutierrez E, Gutierrez-Dias E, Redondo-Marcos I, Ricoy JR, García-Torre JP: Cutaneous horns of the eyelid: a clinicopathological study of 48 patients. J Cutan Pathol. 2004, 31:539-543. 10.1111/j.03036987.2004.00226.x

9. Shahi S, Bhandari TR, Pantha T: Verrucous carcinoma in a giant cutaneous horn: a case report and literature review. Case Rep Otolaryngol. 2020, 2020:7134789. 10.1155/2020/7134789

10. Peterson JL, McMarlin SL: Metastatic renal-cell carcinoma presenting as a cutaneous horn. J Dermatol Surg Oncol. 1983, 9:815-818. 10.1111/j.1524-4725.1983.tb00737.x

11. Sandbank M: Basal cell carcinoma at the base of cutaneous horn (cornu cutaneum) . Arch Dermatol. 1971, 104:97-98. 10.1001/archderm.1971.04000190099021 